\title{
IMPLEMENTASI KEBIJAKAN PERATURAN DAERAH KABUPATEN MUSI BANYUASIN NO 11 TAHUN 2016 TENTANG KAWASAN TANPA ROKOK PADA DINAS KESEHATAN KABUPATEN MUSI BANYUASIN
}

\author{
${ }^{1}$ Sisca Nopralia, ${ }^{2}$ Hermansyah, ${ }^{3}$ Isma Nirmala, ${ }^{4}$ Siti Waliah \\ ${ }^{1}$ Fakultas Ilmu Administrasi Universitas Sjakyakirti, Email: sisca_nopralia@unisti.ac.id \\ ${ }^{2}$ Fakultas Ilmu Administrasi Universitas Sjakyakirti, Email: hermansyah@unisti.ac.id \\ ${ }^{3}$ Fakultas Ilmu Administrasi Universitas Sjakyakirti, Email: Ismanirmala53@gmail.com \\ ${ }^{4}$ Fakultas Ilmu Administrasi Universitas Sjakyakirti, Email: siti_waliah@ yahoo.co.id
}

\begin{abstract}
The research was carried out at the Musi Banyuasin district health office which is located at Jalan Kol. Wahid Udin No. 230 Kelurahan Kayuara, Sekayu District, Postal Code 30711, Sekayu, South Sumatra. The research used a descriptive approach, namely solving problems investigated by describing, describing the condition of the subject / object of the study (a person, institution, community, etc.) based on the facts and then described descriptively. The formulation of the problem examined in the study was How to Implement Regional Regulation number 11 of 2016 regarding smoking-free areas at the Musi Banyuasin District Health Office. Data collection techniques used are interviews, observation and documentation. The implementation model used is the implementation model according to George C. Edward III which includes four elements, namely communication measured through indicators of clarity and consistency, resource elements measured through staff indicators, information, authority, and facilities, disposition elements measured by appointment. employees and incentives, as well as elements of bureaucratic structure as measured by indicators of standard operating procedures (SOPs) and fragmentation. The results of the research that have been concluded are the implementation of Regional Regulation number 11 of 2016 concerning smoking-free areas at the Musi Banyuasin District Health Office which analyzed with the four elements above that have been communicated actively and clearly, including both vertical (superior to subordinate) and horizontal (among staff) directly or indirectly, have the resources to support it. The resources in question include competent and capable human resources $(H R)$ as well as budgetary resources (SDA) originating from APBD funds, the disposition (attitude and willingness) of implementers who are involved in implementing the regional regulations without smoking are those who work. based on their capabilities and expertise, according to standard operating procedures (SOPs) and fragmentation (coordination of tasks) internally and externally.
\end{abstract}

Keywords: Implementation, Regional Regulations, No Smoking Areas

\begin{abstract}
ABSTRAK
Penelitian dilakukakan pada Kantor dinas kesehatan kabupaten Musi Banyuasin yang beralamat di jalan Kol. Wahid Udin No. 230 Kelurahan Kayuara Kecamatan Sekayu, Kode Pos 30711, Sekayu, Sumatera Selatan. Penelitian menggunakan metode pendekatan deskriptif, yaitu pemecahan masalah yang diselidiki dengan menggambarkan, melukiskan keadaan subyek/ obyek penelitian (seorang, lembaga, masyarakat dan lain-lain) berdasarkan fakta-fakta kemudian dipaparkan secara deskriptif. Rumusan masalah yang diteliti dalam penelitian adalah Bagaimana Implementasi Peraturan Daerah nomor 11 tahun 2016 tentang kawasan tanpa rokok pada kantor Dinas Kesehatan kabupaten Musi Banyuasin. teknik pengumpulan data yang digunakan yaitu wawancara, observasi dan dokumentasi. Model implementasi yang digunakan adalah model implementasi menurut George C Edward III yang meliputi empat unsur, yaitu komunikasi yang di ukur melalui indikator kejelasan dan konsistensi, unsur sumberdaya yang diukur melalui indikator staf, informasi, wewenang, dan fasilitas, unsur disposisi yang diukur melalui pengangkatan pegawai dan insentif, serta unsur struktur birokrasi yang diukur melalui indikator standar operating prosedures (SOPs) dan fragmentasi. Hasil dari penelitian yang telah disimpulkan adalah Implementasi Peraturan Daerah nomor 11 tahun 2016 tentang kawasan tanpa rokok pada Kantor Dinas Kesehatan kabupaten Musi Banyuasin yang dianalisis dengan keempat unsur diatas telah dikomunikasi secara aktif dan jelas, baik meliputi komunikasi vertikal (atasan kepada bawahan) maupun horizontal (antar staf) secara langsung maupun tidak langsung, memiliki sumber daya yang mendukung. Sumber daya yang dimaksud meliputi sumber daya manusia (SDM) yang kompeten dan memiliki kemampuan yang memadai maupun sumber daya anggaran (SDA) yang berasal dari dana APBD, disposisi (sikap
\end{abstract}


dan kemauan) implementor yang terlibat dalam pelaksanaan Perda kawasan tanpa rokok adalah mereka yang bekerja dengan berdasarkan kemampuan dan keahlian yang mereka miliki, sesuai standar operating prosedures (SOPs) dan fragmentasi (koordinasi tugas) secara internal maupun eksternal.

Kata Kunci: Implementasi, Peraturan Daerah, Kawasan Tanpa Rokok

\section{A. PENDAHULUAN}

\section{Latar Belakang}

Kawasan tanpa asap rokok adalah tempat atau ruangan yang dinyatakan dilarang untuk merokok, memproduksi, menjual, mengiklankan dan mempromosikan rokok . larangan tersebut baik ruangan terbuka maupun tertutup sampai pagar pembatas area yang ditetapkan kawasan tanpa rokok Tempat itu adalah Sarana Kesehatan, Tempat Proses Belajar Mengajar, Tempat Ibadah, Sarana Kegiatan Olah Raga, Arena Kegiatan Anak, Angkutan Umum,Tempat Kerja, Tempat Umum.

Sosialisasi yang telah dilaksanakan dalam bentuk Baliho, Spanduk, Stiker, Serta Seminar Kesehatan tentang Kawasan Tanpa Rokok tidak mempengaruhi masyarakat untuk tidak merokok di kawasan yang telah ditentukan. Buktinya, Peraturan Daerah Kabupaten Musi Banyuasin Nomor 11 Tahun 2016 tentang Kawasan Tanpa Asap Rokok dilaksanakan sejak di mulai diberlakukan 9 November 2016.

Asap rokok terdiri dari asap utama (main stream) yang mengandung 25\% kadar bahan berbahaya dan asap samping gan (side stream) yang mengandung $75 \%$ bahan berbahaya. Perokok pasif mengisap $75 \%$ bahan berbahaya ditambah separuh dari asap yang dihembuskan keluar dari perokok. Asap rokok orang lain atau yang sering disebut dengan AROL adalah asap yang keluar dari ujung rokok yang menyala atau produk tembakau lainnya, yang biasanya merupakan gabungan dengan asap rokok yang dikeluarkan oleh perokok.

Kebijakan penerapan Kawasan Tanpa Rokok juga mesti didukung dengan kepatuhan dan kepedulian masyarakat mengenai kebijakan tersebut, sehingga Kebijakan pemerintah tentang area bebas rokok nantinya akan mampu menyelamatkan nasib perokok pasif melihat banyaknya jumlah perokok aktif yang ada.

\section{Identifikasi Masalah}

Supaya penelitian ini berjalan sesuai dengan apa yang diharapkan, maka diperlukan suatu identifikasi masalah yang berfungsi untuk mengarahkan dan memfokuskan penelitian ini hanya pada aspek-aspek sebagai berikut :

1. Kurang kesadaran perokok akan kesehatan

2. Belum adanya sanksi tegas yang diberikan kepada perokok yang melanggar

3. Peraturan daerah Nomor 11 Tahun 2016 tentang Kawasan Tanpa Rokok hanya sekedar wacana.

\section{Pembatasan Masalah}

Untuk menghindari penelitian ini nantinya tidak terfokus pada permasalahan yang akan diteliti, maka penelitian ini dibatasi pada Kebijakan Peraturan Daerah Kabupaten Musi Banyuasin No 11 Tahun 2016 tentang Kawasan Tanpa Rokok.

\section{Perumusan Masalah}

Dari latar belakang yang telah dikemukakan maka rumusan masalahnya adalah Bagaimana Kebijakan Peraturan Daerah Kabupaten Musi Banyuasin No 11 Tahun 2016 tentang Kawasan Tanpa Rokok.

\section{Signifikan Penelitian}

Tujuan penelitian yang ingin dicapai Untuk mengetahui dan memperoleh gambaran yang jelas tentang Kebijakan Peraturan Daerah Kabupaten Musi Banyuasin No 11 Tahun 2016 tentang Kawasan Tanpa Rokok.

\section{Kajian Penelitian Sebelumnya}

L Purwantiningtias (2015) Peraturan Daerah kota Surabaya nomor 5 tahun 2008 tentang kawasan tanpa rokok dan kawasan terbatas menyebutkan bahwa faktor penghambat antara lain anggaran terbatas. 
Purwo Setiyo Nugroho (2015) Evaluasi implementasi kawasan tanpa rokok Surakarta menyebutkan bahwa adanya peraturan daerah mengenai kawasan tanpa rokok, adanya teguran bagi yang merokok, adanya klinik berhenti merokok (KBM) dan dukungan dana bagi KBM merupakan faktor pendukung KTR . Kurang maksimalnya sosialisasi, edukasi, fungsi KBM. Masih ditemukan banyak yang merokok.

\section{B. KAJIAN PUSTAKA \\ 1. Kebijakan Publik}

Dari segi bahasa kebijakan berasal dari bahasa Yunani dan Sansakerta Polis (negara kota) dan Pur (kota), kemudian diterjemahkan dalam bahasa latin menjadi Politea(negara) sedangkan dalam bahasa inggris Policy yang berkenaan dengan pengendalian masalahmasalah politik atau administrasi pemerintah. Kata policy memiliki kesamaan dengan kata policy an politics (Muhajir Darwan, 1990:10). Istilah policy (kebijaksanaan) seringkali penggunaanya disamakan dengan istilahistilah lain seperti tujuan (goals), program keputusan, undang-undang, dan ketentuanketentuan.

Sedangkan menurut Anderson, pengertian kebijakan adalah kebijakan-kebijakan yang dikembangkan oleh badan-badan dan pejabatpejabat pemerintah.

Anderson mengemukakan bahwa terdapat 5 (lima) hal yang berhubungan dengan kebijakan-kebijakan publik, yaitu:

1. Tujuan atau kegiatan yang berorientasi tujuan haruslah menjadi perhatian utama perilaku acak atau peristiwa yang tibatiba

2. Kebijakan merupakan pola atau model tindakan pejabat pemerintah mengenai keputusan-keputusan diskresinya secara terpisah

3. Kebijakan harus mencakup apa yang nyata pemerintah perbuat, bukan apa yang mereka maksud untuk berbuat, atau apa yang mereka katakan akan dikerjakan

4. Bentuk kebijakan bisa berupa hal yang positif atau negartif
5. Kebijakan publik dalam bentuknya yang positif didasarkan pada ketentuan hukum dan kewenangan

Sementara, menurut Frederock (Wahab, 1991:13) kebijakan diartikan sebagai suatu tindakan yang mengarah pada tujuan yang diusulkan oleh seseorang, kelompok atau pemerintah dalam lingkungan tertentu sehubungan dengan adanya hambatanhambatan tertentu, seraya mencari peluangpeluang untuk mencapai tujuan atau mewujudkan sasaran yang diinginkan.

Defenisi diatas dapat dikatakan bahwa berarti pemerintah harus mempunyai kemampuan yang dapat dihadapi, dengan memperhatikan sumber daya yang dimiliki serta menerima masukan atau usulan dari seseorang/kelompok, sehingga ada jalan keluar yang terbaik, dihasilkan melalui proses yang fair. Tahapan pembuatan kebijakan merupakan kegiatan yang tersusun, sebagiamana menurut William Dunn (LAN dan BPK, 2000), sebagai berikut:

1. Tahapan penyusunan agenda digunakan untuk merumuskan masalah, mendefinisikan masalah dan memulai proses pembuatan kebijakan melalui penyusunan agenda

2. Tahapan formulasi kebijakan, merupakan tahapan yang dilakukan oleh para pejabat instansi pemerintah untuk merumuskan alternatif kebijakan dalam mengatasi masalah. Dalam tahapan ini teknik peramalan dapat dipergunakan untuk menyajikan pengetahuan mengenai timbulnya kemungkinan masalah ataupun kendala yang akan terjadi pencapaian dimasa mendatang akibat diambilnya suatu alternatif kebijakan

3. Tahapan adopsi kebijakan, merupakan tahapan dalam mengimplementasikan suatu kebijakan. dalam tahap ini suatu rekomendasi diperlukan upaya memahami biaya menfaat dari berbagai alternatif kebijakan dan segala kemungkinan akibatnya dimasa mendatang

4. Tahapan implementasi kebijakan, merupakan tahapan dalam merealisasikan alternatif kebijakan yang telah dipilih 
5. Tahapan penilaian kebijakan, merupakan tahapan evaluasi, dengan adanya suatu evaluasi guna mendapatkan pengetahuan yang relevan mengenai hasil kerja kebijakan

Berhasil tidaknya suatu kebijakan dapat diketahui evaluasi kebijakan dengan yang memiliki fungsi menurut William Dunn (Muhadjir, 1994:609) sebagai berikut:

1. memberikan informasi yang valid dan dapat dipercaya mengenai kinerja yaitu seberapa jauh kebutuhan, nilai dan kesempatan telah dapat dicapai melalui tindakan publik.

2. Memberikan sumbangan pada klarifikasi dan kritik terhadap nilai-nilai yang mendasari pemikiran tujuan dan target.

3. Memberi sumbangan pada aplikasi dan metode analisis kebijakan lainnya, termasuk perumusan masalah dan rekomendasi.

Tujuan kebijakan publik adalah dapat dicapainya kesejahteraan masyarakat melalui peraturan yang dibuat oleh pemerintah. Thomas R.Dye menjelaskan bahwa kebijakan publik adalah apa saja yang dipilih oleh pemerintah untuk dilakukan atau tidak dilakukan, apabila pemerintah memilih untuk melakukan sesuatu maka harus ada tujuan dan kebijakan negara tersebut harus meliputi semua tindakan pemerintah, bukan sematamata pernyataan keinginan pemerintah atau pejabatnya. Disamping itu, sesuatu yang tidak dilaksanakan oleh pemerintah juga termasuk kebijakan negara. Hal ini disebabkan sesuatu yang tidak dilakukan oleh pemerintah akan mempunyai pengaruh yang sama besarnya dengan sesuatu yang dilakukan oleh pemerintah.

\section{Peraturan Daerah Kabupaten Musi Banyuasin No 11 Tahun 2016 tentang Kawasan Tanpa Rokok}

Dikemukan bahwa peraturan daerah (perda) nomor 11 tahun 2016 tentang kawasan tanpa rokok. Perda ini dimaksudnya bukan melarang orang untuk merokok, melainkan hanya mengatur bahwa di Kabupaten Musi Banyuasin terdapat beberapa tempat yang dinyatakan sebagai kawasan tanpa rokok. Kalaupun ada keinginan orang untuk merokok dikawasan tersebut, maka dipersilahkan merokok diluar kawasan tersebut.

Sesuai dengan peraturan daerah (perda) nomor 11 tahun 2016 pasal 24 dan 25 tentang sanksi adminstarif dan sanksi pidana bagi pelanggaran dikawasan tanpa rokok dikantor dinas kesehatan kabupaten Musi Banyuasin, berupa:

1. Sanksi administratif bagi penanggung jawab kawasan tanpa rokok diberikan sanksi berupa peringatan tertulis, paksaan pemerintahan, uang paksa; dan/atau pencabutan izin

2. Sanksi pidana bagi orang yang merokok dikenakan sanksi pidana penjara paling lama 3 (tiga) hari atau denda paling banyak Rp.50.000,- (lima puluh ribu rupiah)

3. Sanksi pidana bagi setiap orang/badan yang mempromosikan, mengiklankan, menjual, dan/atau membeli rokok diarea kawasan tanpa rokok, dipidana dengan pidana penjara paling lama 7 (tujuh) hari atau denda paling banyak Rp.1.000. 000,(satu juta rupiah)

4. Setiap pengelola kawasan tanpa rokok yang tidak melakukan pengawasan internal, membiarkan orang merokok, tidak menyingkirkan asbak dan sejenisnya, dan tidak memasang tandatanda dilarang merokok ditempat atau area yang dinyatakan sebagai KTR dipidana penjara selama 15 (lima belas) hari atau denda paling banyak 10.000.000,- (sepuluh juta rupiah);

\section{Implementasi}

Pelayanan yang diberikan kepada masyarakat dengan adanya jaringan komputerisasi menjadi lebih cepat dan tentukan dapat menghemat pengeluaran biaya. Pelayanan tersebut terjadi sudah tidak membutuhkan tenaga manusia lagi melainkan yang dibutuhkan manusia yang memiliki keahlian untuk mengoperasikan jaringan komputerisasi tersebut. Oleh karena itu, dalam menunjang terciptanya ketertiban administrasi dan peningkatan pelayanan publik, perlu didukung dengan adanya implementasi pada pelayanan dan tujuan yang ingin dicapai. 
Secara etimologis pengertian implementasi menurut kamus webster yang dikutip oleh Solichin Abdul Wahab, adalah:

Konsep implementasi berasal dari bahasa inggris yaitu to implement. Dalam kamus besar webster, to implement (mengimplementasikan) berarti to provide the means for carrying out (menyediakan sarana untuk melaksanakan sesuatu); dan to give practical effect to (untuk menimbulkan dampak/akibat terhadap sesuatu (webster dalam Wahab, 2004:64)

Implemetasi berasal dari bahasa inggris yaitu to implementyang berarti mengimplementasikan. Implementasi merupakan penyediaan sarana untuk melaksanakan sesuatu yang menimbulkan dampak atau akibat terhadap sesuatu.

Model Edward III (Leo Agustino, 2008:150) mengajukan 4 (empat) faktor atau variabel yang berpengaruh terhadap keberhasilan atau kegagalan implementasi kebijakan.

\section{Kerangka Pemikiran}

Telah dikemukan pada uraian sebelumnya bahwa peraturan daerah (perda) nomor 11 tahun 2016 tentang kawasan tanpa rokok. Perda ini dimaksudnya bukan melarang orang untuk merokok, melainkan hanya mengatur bahwa di kabupaten Musi Banyuasin terdapat beberapa tempat yang dinyatakan sebagai kawasan tanpa rokok, dalam hal penelitian ini dkhususkan dikantor Dinas Kesehatan. kalaupun ada keinginan orang untuk merokok dikawasan tersebut, maka dipersilahkan merokok diluar kawasan tersebut. Akan tetapi, pada pelaksanaan dan implementasinya masih ada saja yang melanggar peraturan tersebut.

Menurut George C.Edward III. Faktorfaktor yang mempengaruhi implementasi kebijakan adalah komunikasi, sumber daya, disposisi dan struktur birokrasi. Untuk mengetahui implementasi kebijakan peraturan daerah (perda) nomor 11 tahun 2016 tentang kawasan tanpa rokok pada kantor kesehatan dinas kabupaten Musi Banyuasin agar tercapainya secara efektif peraturan daerah tentang kawasan tanpa rokok.
Keempat faktor-faktor yang mempengaruhi implementasi kebijakan dalam model implementasi menurut George C.Edward III tersebut dapat digambarkan sebagai berikut:

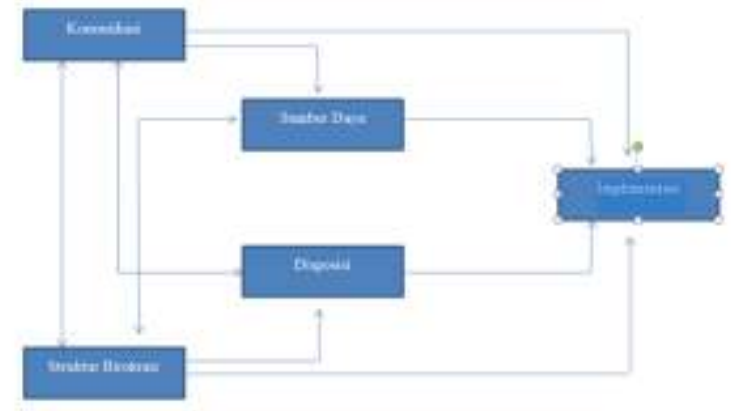

\section{METODOLOGI PENELITIAN \\ 1. Tujuan Penelitian}

Untuk mengetahui dan memperoleh gambaran yang jelas tentang Implementasi Kebijakan Peraturan Daerah Kabupaten Musi Banyuasin No 11 Tahun 2016 tentang Kawasan Tanpa Rokok.

\section{Tempat dan Waktu Penelitian}

Penelitian ini dilaksanakan pada salah satu kantor pemerintahan di Kabupaten Musi Banyuasin. Dengan waktu penelitian mulai dari 14 Agustus 2017 sampai dengan 17 Maret 2018 .

\section{Metode dan Desain Penelitian}

Desain Penelitian yang dilakukan peneliti adalah menggunakan pendekatan deskriptif dengan metode kualitatif. Penelitian kualitatif adalah penelitian yang pada umumnya dikaitkan dengan epistemologi positivisme, dan biasanya dilihat sebagai kegiatan pengumpulan dan analisis data berupa angkaangka. Penelitian deskriptif dimaksud untuk menemukan jawaban terhadap masalah yang diteliti dengan cara tertentu sesuai dengan masalah dan jenis data yang diperlukan. Pemilihan metode deskriptif dianggap sangat tepat karena sesuai dengan tujuan atau masalah dalam penelitian ini, yaitu memperoleh gambaran secara obyektif tentang pelaksanaan peraturan daerah Kabupaten Musi Banyuasin nomor 11 tahun 2016 tentang kawasan tanpa rokok. 


\section{Informant Penelitian}

Informan merupakan pemberi informasi atau orang yang menjadi kunci atas sebuah informasi. Informan dalam penelitian ini adalah kepala bidang pengendalian masalah di dinas kesehatan kabupaten Musi Banyuasin, serta informant pendukung lainnya yaitu: kepala bidang Pengendalian dan Pemberantasan Penyakit, kepala seksi pengendalian dan pemberantasan penyakit di dinas kesehatan kabupaten Musi Banyuasin.

\section{Sumber Data}

Data dalam penelitian ini merupakan fokus penelitian untuk menentukan apa saja yang akan dikaji dari sebuah penelitian sehingga lebih jelas apa yang diinginkan. Oleh karena itulah peneliti ingin mengetahui dan mendalami berjalan atau tidaknya peraturan daerah Kabupaten Musi Banyuasin nomor 11 tahun 2016 tentang kawasan tanpa rokok.

Dalam penelitian ini, sumber data yang dikumpulkan adalah data primer dan data sekunder. Data primer yaitu data yang diperoleh langsung dari wawancara atau observasi berupa kata-kata dan tindakan orang yang diwawancarai dan diamati. Sedangkan untuk data sekunder diperoleh melalaui dinas/instansi terkait. Yakni sumber-sumber tertulis baik berupa buku-buku, majalah, jurnal ilmiah, dokumen, arsip dan data yang telah diteliti serta dikumpulkan oleh pihak lain yang berkaitan dengan permasalahan penelitian ini.

\section{Teknik Pengumpulan Data}

Teknik yang digunakan dalam mengumpulkan data antara lain dengan cara : Wawancara

Metode wawancara merupakan sebuah metode pengumpulan data dengan mengajukan beberapa pertanyaan secara langsung kepada responden atau pihak terkait untuk memperoleh penjelasan pendapat, sikap dan keyakinan tentang hal-hal relevan dalam penelitian. Menurut Lexy J Maelong (2002:135) wawancara adalah percakapan dengan maksud tertentu dan dilakukan dengan dua pihak yaitu pewawancara dan yang memberikan jawaban atas pertanyaan tersebut (responden).

\section{Observasi}

Teknik observasi atau pengamatan didasarkan pada pengalaman secara langsung. Jika suatu data yang diperoleh kurang meyakinkan atau untuk menguji keabsahan data yang diperoleh dengan realita dilapangan, biasanya peneliti melakukan

pengamatan dan mempelajari secara langsung kejadian-kejadian dilapangan.

\section{Dokumentasi}

Dokumentasi sebagai laporan tertulis dari suatu peristiwa yang isinya terdiri dari penjelasan dan pemikiran terhadap peristiwaperistiwa itu dan ditulis dengan sengaja untuk menyimpan atau menemukan keterangan mengenai peristiwa tersebut, yang bertujuan untuk menguji, menafsirkan serta meramalkan. Dengan menggunakan teknik ini, penyusunan akan memperoleh data dengan melihat dokumen-dokumen yang berupa laporanlaporan, peraturan daerah, dan sebagainya sesuai dengan kebutuhan dalam penelitian ini.

\section{Teknik Analisis Data}

Penelitian ini menggunakan dua pendekatan yaitu pendekatan kualitatif deskriptif dengan memposisikan analisa data kualitatif untuk memperjelas data-data kualitatif yang telah diperoleh dalam penelitian. Teknik analisa data sendiri dalam penelitian ini adalah metode triangulasi.

Triagulasi pada hakikatnya merupakan pendekatan multimedia yang dilakukan peneliti pada saat mengumpulkan dan menganalisis data. Pemikiran dasar dalam penggunaan metode triagulasi adalah bahwa fenomena yang diteliti dapat dipahami dengan baik sehingga diperoleh kebenaran tingkat tinggi jika didekati dari sudut pandang yang berbeda-beda akan memungkinkan diperoleh tingkat kebenaran yang handal. Oleh karena itu, triagulasi ialah usaha mengecek kebenaran data atau informasi yang diperoleh peneliti dari berbagai dengan cara mengurangi sebanyak mungkin perbedaan yang terjadi pada saat pengumpulan data analisis data.

\section{HASIL PEMBAHASAN}

1. Gambaran Umum Lokasi Penelitian

Dalam penelitian ini penulis akan menggambarkan gambaran daerah penelitian 
yaitu pada Kantor Dinas Kesehatan Kabupaten Musi Banyuasin yang berada di kota Sekayu , Sumatera Selatan tepatnya di Jalan Kol. Wahid Udin No. 230 Kelurahan Kayuara Kecamatan Sekayu, Kode Pos 30711.

\section{Pembahasan}

Proses implementasi kebijkan tentang peraturan daerah nomor 11 tahun 2016 tentang kawasan tanpa rokok (KTR) pada kantor Dinas Kesehatan kabupaten Musi Banyuasin terdapat berbagai faktor yang mempengaruhi implementasi kebijakan. sebagaimana yang dikemukan oleh George C.Edward III (1980) keempat faktor tersebut meliputi faktor komunikasi, sumber daya, disposisi, dan struktur birokrasi.

Keempat faktor tersebut dalam mengimplementasikan peraturan daerah (perda) kabupaten Musi Banyuasin nomor 11 tahun 2016 tentang KTR merupakan faktor yang mempengaruhi keberhasilan dan kegagalan implementasi kebijakan peraturan daerah nomor 11 tahun 2016 tentang kawasan tanpa rokok pada dinas kesehatan kabupaten Musi Banyuasin sudah tercukupi dan memadai, Koordinasi tersebut tidak hanya berlangsung secara internal, tetapi juga meliputi koordinasi eksternal dengan pihak luar untuk berpartisipasi dalam mendukung pelaksanaan dan pengawasan kawasan tanpa rokok. Koordinasi yang baik tentu akan memberikan hasil yang positif dalam pelaksanaan implementasi Perda nomor 11 tahun 2016 tentang kawasan tanpa rokok pada kantor Dinas Kesehatan kabupaten Musi Banyuasin sesuai dengan tujuan yang ingin dicapai.

\section{E. KESIMPULAN DAN SARAN}

\section{Kesimpulan}

Berdasarkan hasil observasi dan wawancara dengan acuan dasar teori George Edward III yang meliputi aspek komunikasi, sumber daya, disposisi serta struktur birokrasi implementasi Perda nomor 11 tahun 2016 tentang KTR pada kantor Dinas Kesehatan kabupaten Musi Banyuasin telah dijalankan sesuai secara baik,efektif dan efesien untuk mencapai sasaran tujuan implementasi kebijakan tersebut. Berikut uraian hasil dari observasi dan wawancara:

a. Implementasi Perda nomor 11 tahun 2016 tentang kawasan KTR pada Kantor Dinas Kesehatan kabupaten Musi Banyuasin telah dikomunikasi secara aktif dan jelas, baik meliputi komunikasi vertikal (atasan kepada bawahan) maupun horizontal (antar staf) secara langsung maupun tidak langsung

b. Implementasi Perda nomor 11 tahun 2016 tentang kawasan KTR pada Kantor Dinas Kesehatan kabupaten Musi Banyuasin memiliki sumber daya yang mendukung. Sumber daya yang dimaksud meliputi sumber daya manusia (SDM) yang kompeten dan memiliki kemampuan yang memadai maupun sumber daya anggaran (SDA) yang berasal dari dana APBD.

c. Implementasi Perda nomor 11 tahun 2016 tentang kawasan KTR pada Kantor Dinas Kesehatan kabupaten Musi Banyuasin, disposisi (sikap dan kemauan) implementor yang terlibat dalam pelaksanaan Perda kawasan tanpa rokok adalah mereka yang bekerja dengan berdasarkan kemampuan dan keahlian yang mereka miliki.

d. Implementasi Perda nomor 11 tahun 2016 tentang kawasan KTR pada Kantor Dinas Kesehatan kabupaten Musi Banyuasin sesuai standar operating prosedures (SOPs) dan fragmentasi (koordinasi tugas). Koordinasi tersebut tidak hanya berlangsung secara internal, tetapi juga meliputi koordinasi eksternal dengan pihak luar untuk berpartisipasi dalam mendukung pelaksanaan dan pengawasan kawasan tanpa rokok.

\section{Saran}

Berdasarkan kesimpulan tersebut diatas, saran yang dapat diberikan pada kantor Dinas Kesehatan kabupaten Musi Banyuasin, khususnya semua pihak yang terkait dalam impelementasi Perda nomor 11 tahun 2016 tentang KTR, adapun saran yang peneliti berikan yakni implementasi Perda nomor 11 tahun 2016 tentang KTR pada Kantor Dinas 
Kesehatan kabupaten Musi Banyuasin meskipun telah diterapkan dengan cukup baik, akan tetapi keempat unsur yang terdapat dalam model implementasi meliputi unsur komunikasi, sumberdaya, disposisi dan struktur birokrasi harus ditingkatkan dan terus disosialisasikan kepada staf/pegawai secara berkesinambungan.

\section{DAFTAR PUSTAKA}

Agustino, Leo. 2008. Dasar-dasar Kebijakan Publik. Bandung: Alfabeta

Dunn, William N. 2003. Analisis Kebijakan Publik. Yogyakarta: Hanindita

Mazmanian, Daniel dan Paul Sabartier. 1993. Implementation and Public Policy. USA Forsman and Company

Meleong, Lexy J. 2002. Metodologi Penelitian Kualitatif. Bandung: Rosdakarya

Nugroho, Rian. 2007. Analisis Kebijakan. Jakarta: PT. Elex Media Komputindo
Nugroho, Rian. 2003. Kebijakan Publik Formulasi, Implementasi dan Evaluasi. Jakarta: Gramedia

Rakhmat Rakhmat, Firdaus Firdaus, 2019. Dinamika Implementasi Kebijakan Penanggulangan Kemiskinan di Indonesia, JIASK: Jurnal Ilmu Administrasi dan Studi Kebijakan, Vol. 1, No. 2, 2019.

Sugiyono. 2006. Metode Penelitian Administrasi. Bandung: Alfabeta

Sunarno, Siswanto. 2005. Hukum Pemerintahan Daerah di Indonesia. Jakarta: Sinar Grafika

Winarno, Budi. 2002. Kebijakan dan Proses Kebijakan Publik. Yogyakarta: Media Pressindo

Dokumentasi:

Peraturan Daerah kabupaten Musi Banyuasin Nomor 11 tahun 2016 Tentang Kawasan Tanpa Rokok 